course possible that the two kinds of chlorosis may be found to be essentially the same except for certain secondary effects produced by an undue absorption of manganese.

$$
\begin{aligned}
& \text { Porto Rico Agr. Exp. Sta., } \\
& \text { Mayaguez, Porto Rico }
\end{aligned}
$$$$
\text { P. L. GILE }
$$

\section{RELATIVE IMPORTANCE OF FUNGI AND BACTERIA IN SOIL}

To the Editor of Science: In a recent number of ScIence, ${ }^{1}$ Waksman discusses the question: "Do Fungi Live and Produce Mycelium in Soil?" $\mathrm{He}$ answers the question in the affirmative. I have been interested in the same question for some time and have arrived at conclusions slightly different from those to be inferred from Waksman's article.

Waksman has tested for the presence of mycelium by placing a lump of soil about 1 $\mathrm{cm}$. in diameter in the center of a plate of agar (containing Czapek's solution ${ }^{2}$ for nutrient material). After 24 hours at $20-22^{\circ}$ C., he finds that mold hyphæ radiate out into the medium from this lump of soil. If instead of soil he uses a drop of water in which mold spores are suspended, the amount of mycelium produced in 24 hours is very much smaller. From these findings he concludes that such a lump of soil contains living mycelium.

This conclusion is undoubtedly supported by theoretical considerations. The soil is continually showered with mold conidia from the air and without question contains moisture enough to allow them to germinate even if conditions are not favorable for their longcontinued growth. The presence of mushrooms, moreover, in woodland soil and even in fields and lawns, proves beyond doubt that conditions do favor the growth of certain Basidiomycetes, at least. Their mycelium undoubtedly penetrates the soil sufficiently to be present in a lump as large as that used by Waksman. The question of real importance,

1 SCIENCE, N. S., 44, pp. 320-322.

2 Waksman does not publish the formula of this solution, but it has been obtained from him in a personal letter. It is: $\mathrm{MgSO}_{4} 0.5 \mathrm{~g}$., $\mathrm{K}_{2} \mathrm{HPO}_{4} 1 \mathrm{~g}$., $\mathrm{KCl} 0.5$ g., $\mathrm{FeSO}_{4} 0.01$ g., $\mathrm{NaNO}_{3} 2$ g., Sucrose $30 \mathrm{~g}$. , to one liter of water. however, is whether the mycelium is abundant enough in the soil to compare in its activities with the soil bacteria. Waksman does not discuss this question; although from his statement that the plate method gives figures as high as 1,000,000 fungi per gram soil, the natural implication is that they must be nearly as important as bacteria. His actual data, however, show nothing of the sort. $\mathrm{He}$ merely shows that mold hyphæ can be found in lumps of soil $1 \mathrm{~cm}$. in diameter. A lump of soil that size contains many millions of bacteria. Compared to their activities, those of a few mold hyphæ would be quite insignificant.

I have tested several soils by Waksman's method, and have generally obtained results similar to his; but because the information furnished by it is not quantitative, I have modified the method by the use of smaller quantities of soil (crumbs weighing about 10 mg.), with quite different results. Such a crumb of soil should contain, according to the plate method-which is generally acknowledged to give figures that are much too lowperhaps 100,000 bacteria. If fungi are of anything like the same importance as bacteria in soil, one of these crumbs should certainly contain mold hyphæ. Their presence, however, has been indicated only in the case of soil to which large amounts of organic matter (manure or grass roots) have been added. When crumbs of soil to which no organic matter has been added have been used, the development of mold hyphæ in the agar has been slower than in the case of drops of water containing nothing but mold conidia. This certainly suggests that no mycelium is present in these small crumbs and that molds are relatively insignificant in soil; but as the crumbs of soil were always surrounded at the end of 24 hours by vigorously growing bacteria, it is possible that the development of mold hyphæ may have been suppressed. For this reason, Waksman's method is considered inconclusive.

It seems as if the question could be conclusively answered only by the use of a microscope. The microscope would furnish direct instead of presumptive evidence on the sub- 
ject. The reason no one has ever used a microscope in answering this and"similar questions is undoubtedly because it is difficult to distinguish soil microorganisms without staining, and hard to stain them without staining the dead organic matter of the soil so deeply as to obscure the microorganisms. I have been struggling with these difficulties for the last two years and have at last found a method of staining that shows up the microorganisms of the soil without staining the soil particles or the dead organic matter. The details of the method are not yet ready for publication, but will be in a couple of months. Even though the technic is not yet perfected, it has furnished information that helps answer the question discussed by Waksman.

Briefly stated, every kind of soil microorganism except mold hyphæ has been revealed. Bacteria are shown in large numbers. So are Actinomyces conidia; while masses of Actinomyces hyphæ have been observed. Algæ are not uncommon, and objects resembling mold conidia have been found. Some organisms have been observed that are strongly suggestive of protozoa. But of mold hyphæ only an occasional small fragment has been seen, even in soil rich in organic matter. I realize that this microscopic method may, for some unknown reason, fail to reveal mold hyphæ even when they are present; but it is at least a direct method, while Waksman's method is indirect.

Although Waksman was presumably correct in his statement that fungus mycelium is present in soil, it is doubtful whether it exists there to a significant extent. Of course fungi live in soil, particularly when large amounts of organic matter are present; but it is hardly fair to compare their activities with those of bacteria-as has often been done in the past, either directly or by implication-until it is shown that their mycelium is present in soil in sufficient quantities to compare with the large numbers of bacteria that are known to be present in active form.

\section{H. Joel ConN}

New York Agricultural Experiment Station, GENEVA, N. Y.
THE SUDDEN APPEARANCE OF GREAT NUMBERS OF FRESH-WATER MEDUSAE IN A KENTUCKY CREEK

ON the morning of September 27, 1916, there was brought to me a large bottle of creek water in which were the badly decomposed remains of several small gelatinous bodies which to my great surprise were recognized as parts of medusæ. They proved to have come from Benson Creek near Frankfort, about twentyeight miles from Lexington, and had been alive, it was reported, the preceding evening. The bottle of water containing them had been brought to Lexington by Mr. Ben Marshall of the revenue service, at whose Frankfort office it had been left by Mr. C. M. Bridgemord. The latter was said to have asserted that he saw "millions" of the animals in the water. There was reason for some doubt about the "millions," but the evidence of the decomposed bodies showed that there were some in the creek and I could not rest satisfied without examining the locality for myself. With Mr. Marshall I left Lexington in the afternoon and arrived at his office in Frankfort about 4 o'clock P.M., where we found $\mathrm{Mr}$. Bridgemord and Mr. J. L. Cox of the office, who is an ardent angler and had become interested in the animals. These gentlemen very kindly took me in a motor-boat down Kentucky River, and a short distance below the L. \& N. R. R. bridge we turned into the mouth of Benson Creek and proceeded up the stream. Kentucky River has been dammed below this point, so that the water is backed into the lower park of the creek, producing a rather narrow, deep body of water with but little current. We traveled up this backwater for about a half mile, when we reached the point where the medusæ had been captured. The water looked rather bad and unsuited to them at first, but became better farther up, though still not very clear and with its surface roughened by a slight wind. The water was quite warm.

As soon as we reached the part of the stream where the medusæ had been found we began to strain our eyes, attempting to get a glimpse of one in the murky water. Very soon one was seen, a floating, pulsating gray 